Book Power in Communication, Sociology and Technology

Ed. Angela Repanovici, Manolis Koukourakis, Tereza Khecyoyan

Series: Philosophy, Communication, Media Sciences

Available online at http://trivent-publishing.eu/

\title{
The Second Life of Books from Private Collections
}

\author{
Elena Harconița \\ USARB Scientific Library of the Republic of Moldova \\ elena.harconita@mail.ru
}

\begin{abstract}
The key objective of the Scientific Library of „Alecu Russo” Bălți State University (USARB) is to develop information resources and to provide access to the global information network. In this respect, many projects have been developed which attracted considerable investment and sponsorship, including the opening of international centres and private collections. A source of collection enrichment is represented by donations from known or less known personalities from Moldova and abroad. The relationship with owners and heirs of personal libraries has facilitated their donation to the University Library, as well as the diversification of valuable heritage book offers. 11 private collections have completed the collection of the Library with new and unique titles, representing a generous and useful cultural and scientific approach. The geographical area of the titles cover the Republic of Moldova, Romania, Germany, and Sweden. The university librarians manage, promote, and keep all these scientific and cultural treasures for present and future generations.
\end{abstract}

Keywords: information resources; personal libraries; donors, private collections; reading, users

This is an Open Access article distributed in accordance with the Creative Commons Attribution Non Commercial (CC-BY-NC-ND 4.0) license, which permits others to copy or share the article, provided original work is properly cited and that this is not done for commercial purposes. Users may not remix, transform, or build upon the material and may not distribute the modified material (http:/ / creativecommons.org/ licenses/by-nc/4.0/) 


\title{
The Second Life of Books from Private Collections
}

\author{
Elena Harconița \\ USARB Scientific Library of the Republic of Moldova
}

\begin{abstract}
"... Books are like an inheritance passed on from generation to generation for those who will be born."

M. Druc

"The personal library is the mirror of its possessor ... an unmistakable witness of the most intimate spiritual paths."

I. Stoica
\end{abstract}

A source of enrichment of the collections of the Scientific Library of „Alecu Russo” Bălți State University (USARB) are donations from personalities from Moldova and abroad. Due to the generosity of the donors, the USARB Scientific Library benefits today of 10 private collections, comprising 35773 titles, 38633 volumes, at a total value of over 1399537 MDL (66 645 EURO) (Fig. 1), (Fig. 2).

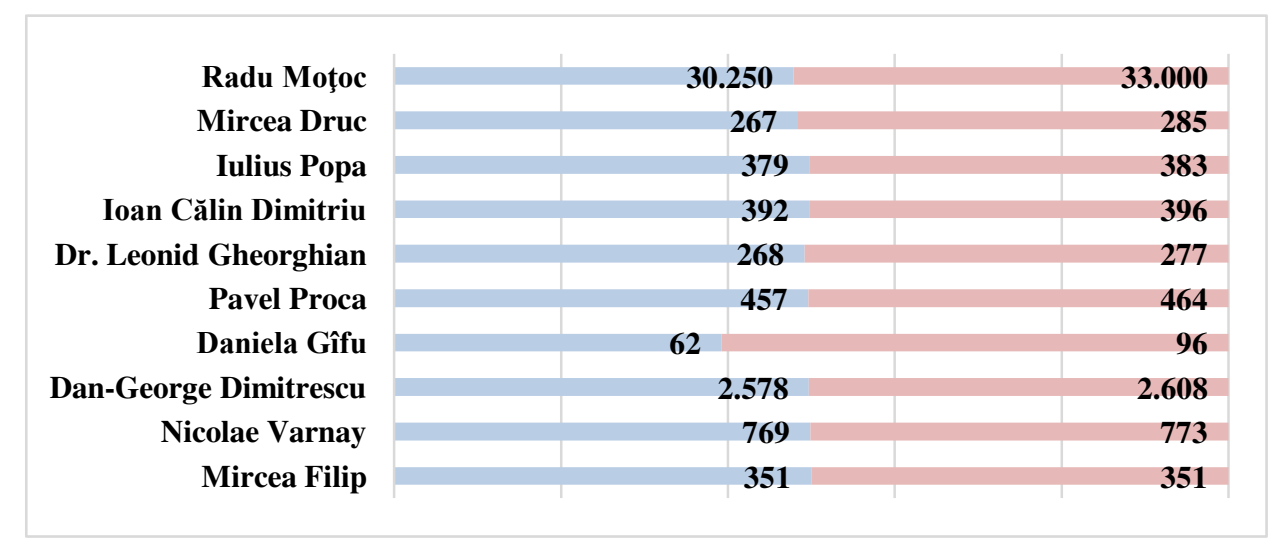

Fig. 1. The Private Collections 

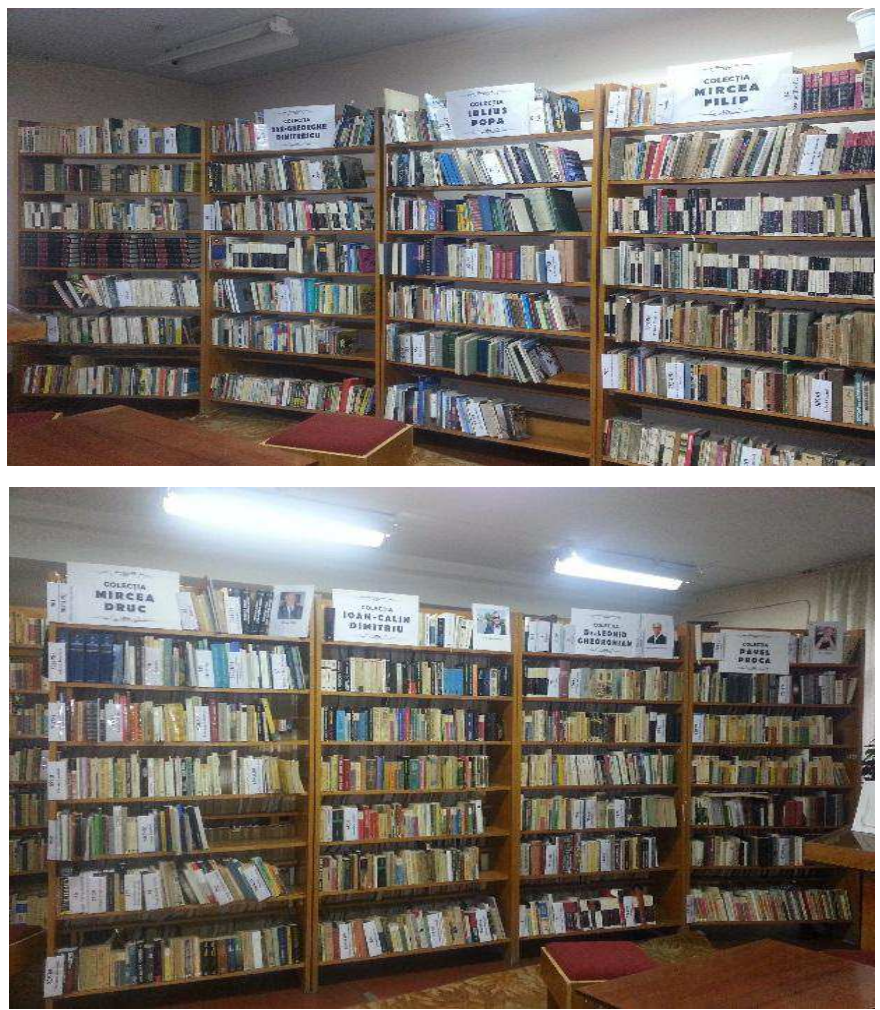

Fig. 2. The Private Collections in open access

Why the Second Life of Books? Because those who gathered and loved them, decided on their fate by offering them to libraries, some of which are not properly funded today. The acquisition of information resources does not correspond to current trends and the Internet's growing monopoly. Therefore, the upgrade of information and communication technologies cannot provide access to publications which may not even be digitized. The gaps in printed collections can be covered by donations of private libraries, thus following Shiyali Ramamrita Ranganathan's five classical laws of library science: Books are for use; Every reader has his/her book; Every book its reader; Save the time of the reader; The library is a growing organism ${ }^{1}$. These collections are important to the content and history of the owner as they are integrated in the cultural and scientific heritage of the Library. University librarians manage and carefully preserve all these books (which may be considered cultural jewellery) for future generations. Furthermore, they exploit and promote the collections through various actions: bibliographic journals, traditional thematic and informative on-line exhibitions, presentations, and book launches. Documents from personal libraries donated to the library contribute to the enrichment of the cultural and scientific heritage of the institution and diversify an informational offer which can be consulted by thousands of users of today and tomorrow.

The books in these collections have special value due to their content and various titles, being produced in various prestigious publishing houses, or coming from known or less

\footnotetext{
${ }^{1}$ R. A Leiter, "Reflections on Ranganathan`s five laws of library science." Law Library Journal 96(3) (2003): 411-418.
} 
known private collections. They contain the donor's autograph, stamp, or ex-libris. By each integrated editorial object in these collections, we become more familiar with the donor's preferences and reading interests.

Our goal is to review some of the peculiarities and beauty of heritage books in these collections. The "Radu Moțoc" collection (Fig. 4, 5) was created thanks to the effort of engineer Radu Moțoc, a descendant of the great family of Ivanco Moțoc (1460 - 1520). The Metropolitan Varlaam (1590-1657) belonged to this family.

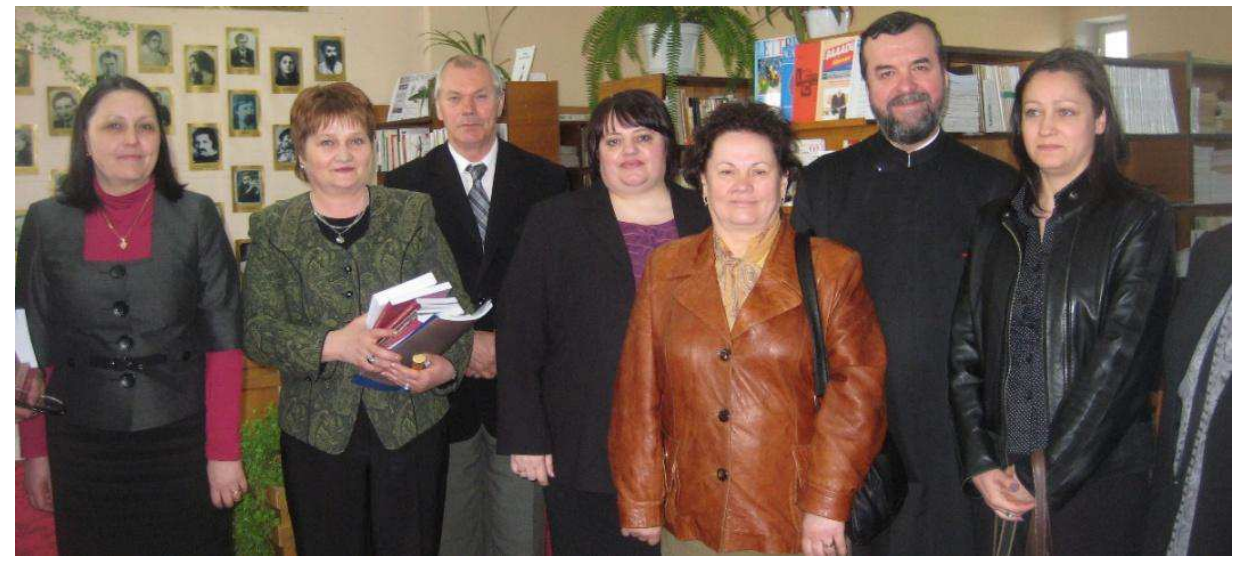

Fig. 3. M. Şleahtițchi, E. Harconița, R. Moțoc, V. Prițcan

It should be noted that our readers owe a great deal to Mr. Radu Moţoc, the secretary of Pro Basarabia and Bucovina Association, "Costache Negri" Branch from Galati, Honorary Member of the University Senate of the Alecu Russo Bălți State University for providing the satisfaction of meeting with the national values of the past. The relations between Balti University Library and Galați started in 1992, when the need for a Romanian book has become extremely urgent..

Numerous letters were sent to big libraries in Romania, to various institutions and associations.

Among the first who answered to our request was Radu Moțoc, who during a period of over 20 years helped to develop the Romanian book collections in the field of Romanian history, language and literature - over 33, 630 volumes worth about 1.5 million RON (100 000 euro), 30643 books, 2335 magazines; 227 CDs, DVDs, and documents in the following languages: Romanian, English, French, German, Spanish .etc. 


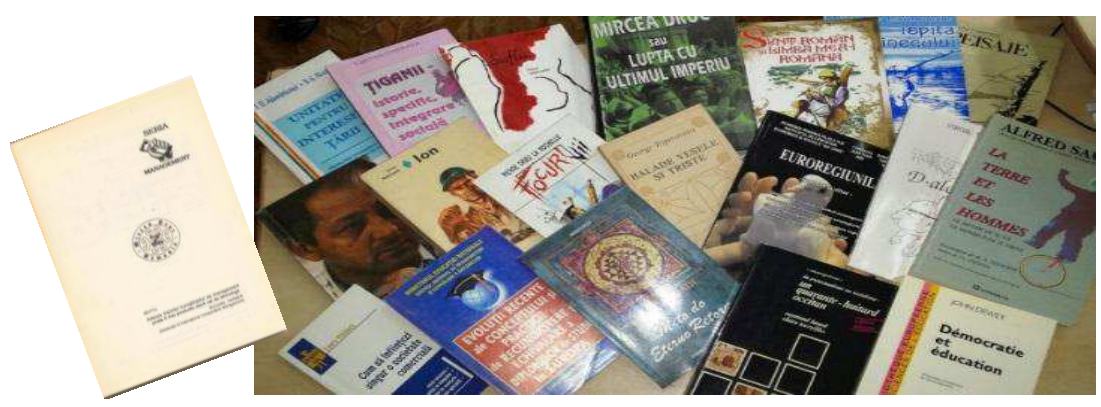

Fig. 4. The "Radu MOTOC" Collection

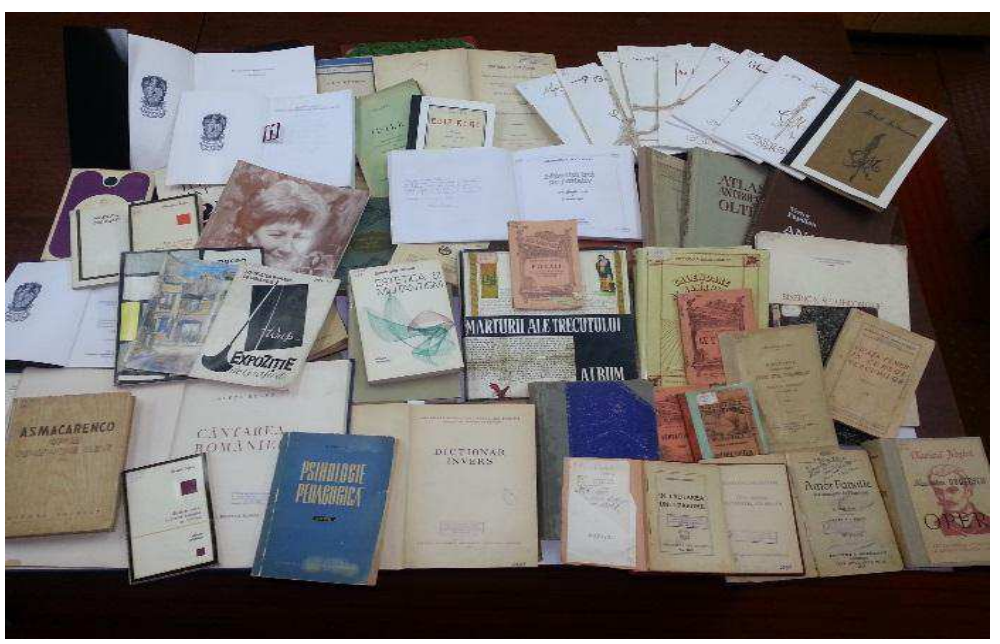

Fig. 5. The "Radu MOTOC" Collection

Some examples marked by ex-libris are the following: Dicționar invers (Reversed Dictionary) (Bucharest, 1957), 43); Sadoveanu, Mihail. Dimineţi de iulie ( July Mornings) (Bucharest, 1927); Vlădescu, G. M. Moartea fratelui meu (My brother's death) (Bucharest, 1934), etc., which have the label on the inside cover: EX LIBRIS MOTOC RADU, Ex-libris: Donation book fund from Cultural Association Pro-Basarabia and Bucovina, Galați Branch, Biblioteca Moțoc (Moțoc Library), Ex-libris Pro-Basarabia and Bucovina Cultural Association Galați Branch, Exlibris: „Engineer Library Radu Motoc” etc., engineer Radu Moțoc as a sign of ownership.

Also, many books in the „Radu Moțoc” collection have autographs or simple thoughts, memories, special dedications: Engineer Radu Motsoc, this son of the Romanian Urban Musatini [dynasty], and to everyone who loves, around, this bit of the Future in the Sol key, from a piece of Romascan - the author. Roman, February 1, 2011 - Gh. A. M. Ciobanu; Technical School of Commerce. Arad. The students' library. No. 3169.

“Mircea Druc" collection (Fig. 6) comes from Mr. Mircea Druc, Prime Minister of the Republic of Moldova during 1990-1991, who donated books from the personal collection through the "Regina Elena" Foundation. He transmitted all his love and affection to the students who will open the pages of his lifetime "fortune."

This collection comprises of 285 documents from the fields of philosophy, social sciences, politics, economics, language, literature, history and periodicals in the following 
languages: Romanian, English, French, Latin and Spanish. Most of the volumes are single copies and each work has the donor's ex-libris.

Among the oldest works according to the year of publication are: Gonseth, Ferdinand. Déterminisme et libre arbitre (les problemes de la philosophie des sciences). - Neuchatel, Ed. du Griffon, 1947; Bujor, I. I. Gramatica limbii latine (Grammar of Latin). - Bucharest, Ed. Ştiinţa, 1958; Hugo, Victor. Omul care rîde (The man who laughs). - in Romanian language by Gellu Naum, Bucharest, Ed. Tineretului, 1961.

The latest document of the collection is published in 2014 "Sunt român și limba mea-i română" "I am Romanian and my language is Romanian"). ${ }^{2}$

Several documents in the collection have the autographs of the authors including: Emil Constantinescu, politician and scientist, former president of Romania; Ion Iliescu, Romanian politician, who served as President of Romania three times; Paul-Philippe de Hohenzollern, also known as Prince Paul of Romania; Leo Butnaru, poet, prose writer; Gheorghe Calamanciuc, playwriter, poet and prose writer, etc.
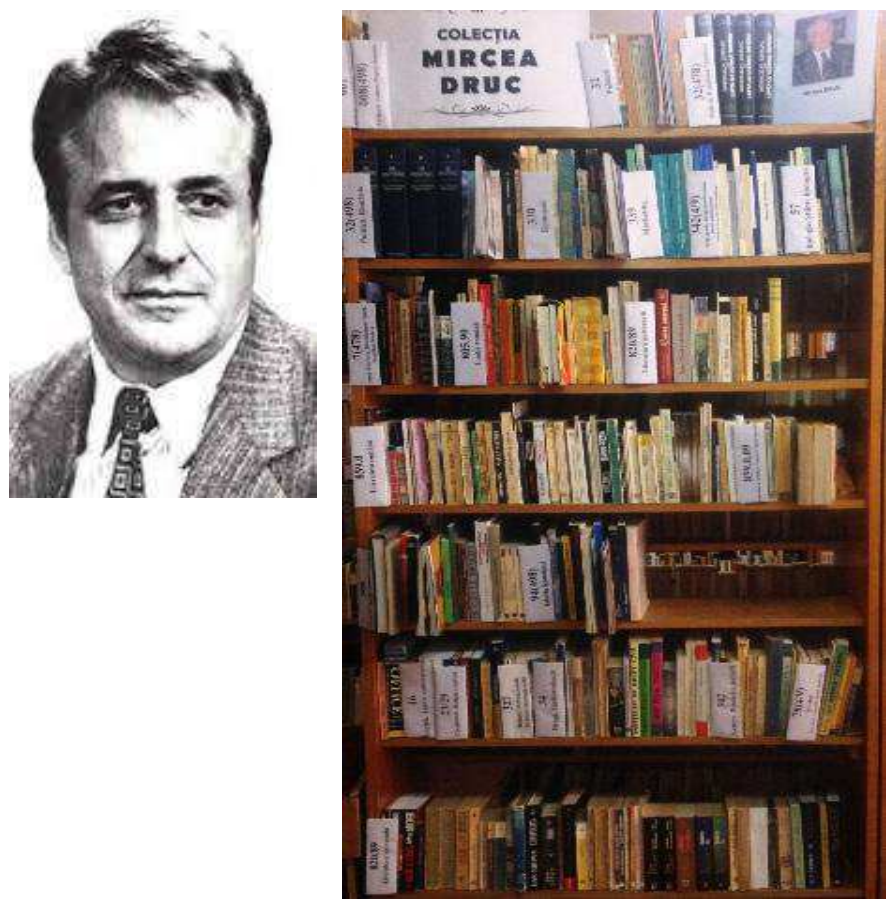

Fig. 6. The "Mircea DRUC" Collection

Mircea Druc is an authentic "landsman." He is a great lover of his country, nation and language. In support of these statements come the titles of the offered papers: "I am Romanian and my language is Romanian," "Unity for the interests of the country!," "Démocratie et educatie."

\footnotetext{
2 Ioan Aurel Pop, ed. Sunt român şi limba mea-i română (Chişinău: Litera, 2014).
} 
Without books, we would be sadder and poorer. Books are like an inheritance passed on from generation to generation for those who will be born (Mircea Druc). ${ }^{3}$

The "Iulius Popa" collection (Fig. 7) belonged to Iulius Popa, journalist and bibliophile, who donated in the summer of 2016 a part of the personal library consisting of over 500 copies, all special books that show the fine and refined taste of the collector.

The donated books represent the most diverse areas of human knowledge: starting with fiction, moving to science, history, soul and health. Documents have been integrated in the open access shelves at the Loan Hall No. 1, Scientific and Fiction Documents. The purposef the collection is to provide "all readers with good books, well chosen, beautiful, interesting and well translated, collected from all the productions of the human spirit." 4

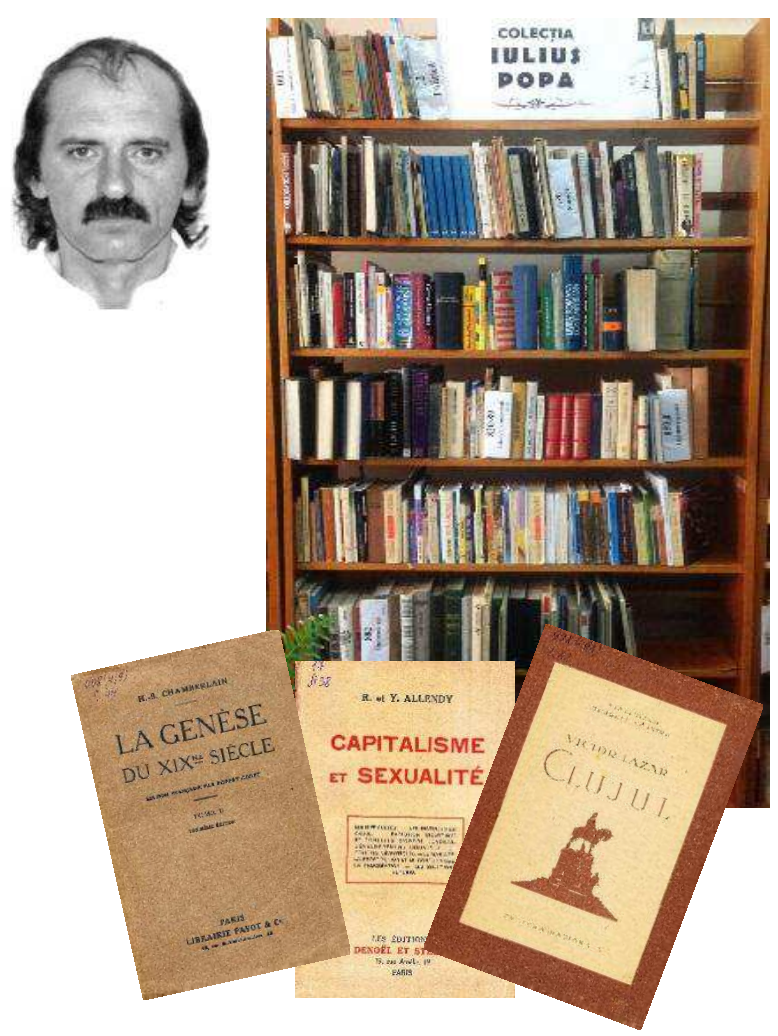

Fig. 7. The "Iulius POPA" Collection

An outstanding gift is represented by rare editions, stored and preserved in the Rare Book collection. The contribution made by bibliophile Iulius Popa is immeasurable, as he is

\footnotetext{
3 Gabriela Cazacu, "Bibliotecile sunt eterne datorită pămîntenilor cu suflet mare: [despre Colecția Mircea Druc de la BŞ USARB] [Libraries are eternal because of big-hearted people - on the "Mircea Druc" Collection of BŞ USARB]" Sintagmele. 2014, V, aug.-sept.: 7.

4 Iulius Popa Collection, http://bs-usarb.blogspot.com/search?q=colec $\% \mathrm{C} 5 \% \mathrm{~A} 3$ ia + iulius + popa (accessed: November 23, 2017).
} 
sharing his wealth with us. He offered the university community books for younger generations. We note some volumes from the rare book collection: Lazar, Victor. Cluj. Bucharest: National Culture. 1923. - 78 p., with numerous paintings, photographs, illustrations, maps. On Endpaper: Exlibris Royal Cultural Foundation. This book is given by His Majesty King Carol II, the King of Romania (1839-1914) through the Royal Cultural Foundations for youth education and for rewarding the students who are heading for culture.

Chamberlain, Houston Stewart. La Genese du XIX-me siecle T. 2. - Paris: Librairie Payot et C-ie, 1913. - 1552 p., bibliophile edition in French on culture, civilization, civilization development, progress and universal history.

The "Ioan Călin Dimitriu" collection (Fig. 8) was offered in 2014 by Irina Dimitriu, Ioan Călin Dimitriu's daughter, who expressed the wish that this collection would be a special fund that bears the name of her father, a computer specialist from Bucharest, Romania. 10 appendices were attached to the donated books.

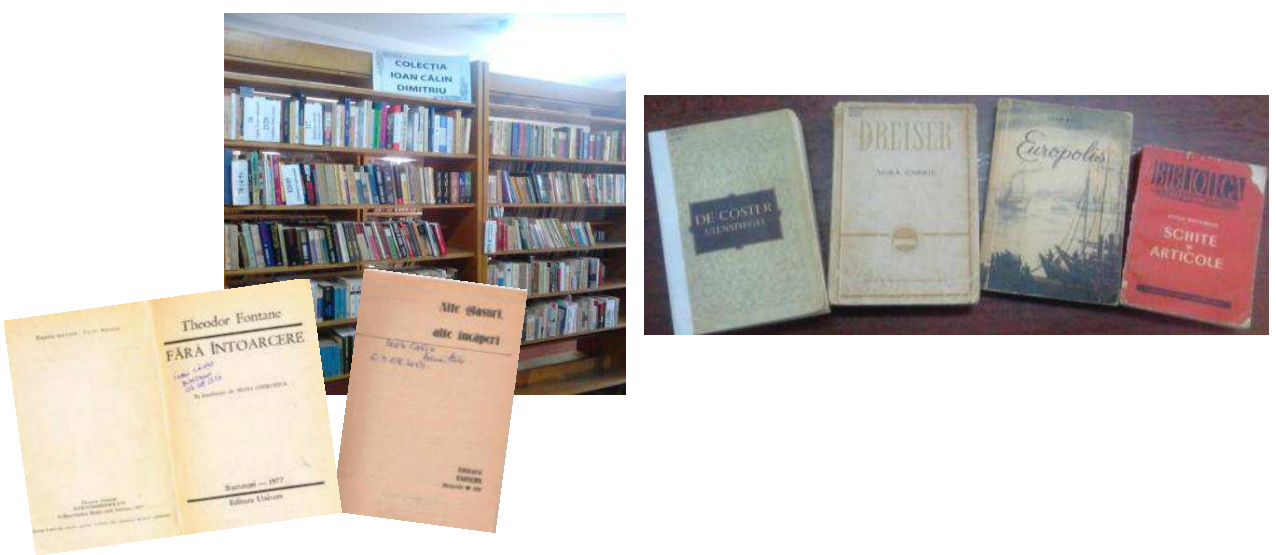

Fig. 8. The "Ioan Călin DIMITRIU" Collection

Ioan Călin Dimitriu was born in Giurgiu in 1945, in a family with great respect for the book. He had a real passion for reading all his life. His favourite reading consisted of books on homeland and universal history. The proof of this passion is represented by a vast library that he has been building over years and which he has always wanted to give away to those who are most in need and also eager to read. Therefore, at the end of Mr. Dimitriu Ioan Calin's life, his daughter donated a part of her father's books collection to Bălți University.

The collection includes 396 documents in various fields such as law, art, history, social sciences, mathematics, medicine, linguistics, language, but mostly Romanian and universal literature in Romanian, English and French. According to the genre of documents, the collection has the following elements: fiction $-81 \%$, scientific $-16 \%$, educational $-3 \%$.

The most beautiful gift in the past was represented by books, thus, some dedication can be found in some books, written by loved ones (daughter, wife, relatives, friends) to Ioan Călin Dimitriu. Here are some examples: Dimitriu Cristina; Dimitriu Ana Cristian; For Ioan Călin Dimitriu, With Love, Adriana Manga Happy Birthday 07 January 2006; Cristina June 27, 1978 Ioan Călin Dimitriu 03.08.2013; Jean Saulea Balti 1967 Pedagogical Institute.

On the title sheet of each volume it is written - Ioan Călin Dimitriu, 03.08.2013. 
From a chronological point of view, the collection documents cover about 75 years, starting with $20^{\text {th }}$ century and ending with books published in 2013.

The book fund holds books that can now be converted to bibliophile values: Coster, Charle: Legenda şi întîmplările vitejești, vesele şi glorioase ale lui Ulenspiegel şi Lamme Goedzak în ținuturile Flandrei şi aiurea. (Ulenspiegel and Lamme Goedzak's legendary and glorious 1 stories in Flanders and other countries). - Bucharest : Ed. de Stat pentru lit. şi artă, 1955. - 571 p.; Dreiser, Theodore. Sora Carrie. - Bucureşti : Ed. de Stat pentru lit. şi artă, 1957. - 516 p.; Bacalbaşa, Anton. Schițe şi articole (Sketches and articles). - Bucharest : Ed. pentru lit. şi artă , 1957. - 431 p.; Bart, Jean. Europolis. - Bucureşti : Ed. de Stat pentru lit. şi artă , 1956. 303 p.: il. and many others.

We find collections that differ in content and graphics, especially: Biblioteca pentru toți (Library for All), FICTION Connection, Globus, Meridiane, Senzațional, Columna, „AltFel” compania, Romanul istoric (Historical novel), Săptămăna Financiară (Financial Week), Thriller, Ştiința afacerii (Business Science), Ion Jalea, Epica magna, Romanul de dragoste (The novel of love), Romanul secolului XX (the Novel of the 20th century), Comando, Christie, Biblioteca RAO (Library $\mathrm{RAO}$ ) and others.

The thematic homogeneity as well as the value of the donated books denote the fact that they were not accidentally acquired by the owner, but went on the thread of permanence of the national historical values. This is the theme of the works that deal with subjects of Roman literature, universal literature, history and language. Elena Cristian mentions in her study „that Ioan Călin Dimitriu tried to gather any note, regardless how little about the Romanian country." 5

The "Dr. Leonid Gheorghian" collection (Fig. 9) was integrated in the library fund in 2014, thanks to Dr. Leonid Gheorghian (place of residence in Germany, Bensheim). He donated from his own library 277 very important copies collected over time.

Leonid Gheorghian was born in Prajila (1929), Soroca district, Republic of Moldova, where he lived during the first years of his childhood (Leonid Gheorghian does not remember this village, considering Balti as the town of his childhood).

The collection holds valuable documents in the fields of culture and civilization, philosophy, history, aesthetics, literature and art. Romanian literature and universal literature prevailed as well as documents printed in Romanian, French and Italian. The documents in the collection have a seal on the title sheet of the book with the ex-libris: "Dr. Leonid Gheorghian. Fachazt fur Radiologie."

\footnotetext{
${ }^{5}$ Elena Cristian, "Colectia particulara a Dlui Ion Calin Dimitriu integrata in colectia Bibliotecii Stiintifice USARB" [The private collection of Mr. Calin Dumitriu from the Scientific Library of USARB] Confluente bibliologice [on-line] 2014 (3-4) : 117-124, http://libruniv.usarb.md/confbib/articole/2014_3-4/Conf\%203-4,2014\%20117-124.pdf http://www.calameo.com/books/001133349bb964f950861 (accessed: November 23, 2017).
} 


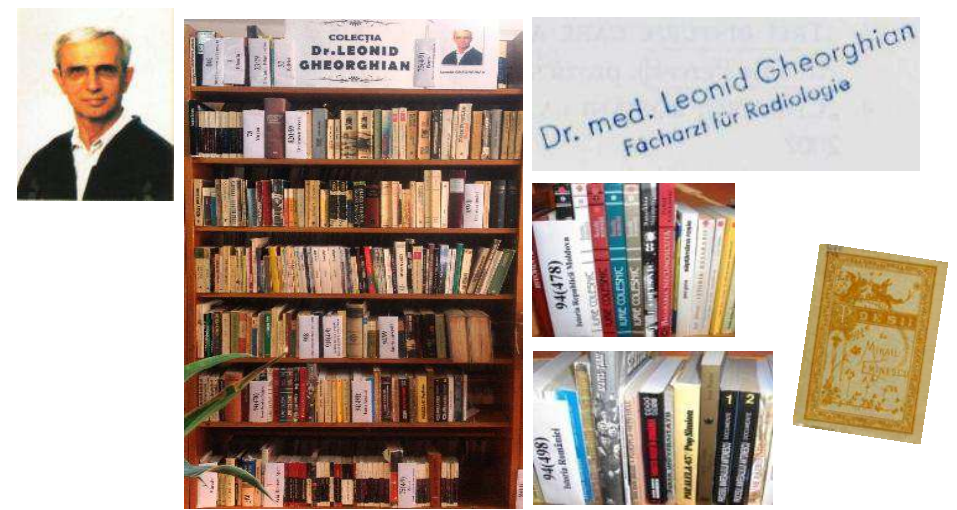

Fig. 9. The "Dr. Leonid GHEORGHIAN" Collection

The oldest document in the collection is the volume of Mihai Eminescu "Poesii," facsimiles published in 1884 (Bucharest, Publishing House SOCECU \& Comp.) The volume includes all the poems of Mihai Eminescu published in "Convorbiri literare" for twelve years, as well as poems in manuscript form. It is the second copy of this document, the first copy being located to the USARB's "Rare Book" collection.

Books come to the user with different messages. As far as universal literature is concerned works of famous universal writers can be discovered: Honore de Balzac, Charles Dickens, William Faulkner, Kafka, Saint-Exupery, Stendhal, Jules Verne, Emile Zola. The Romanian literature is present by the works of Tudor Arghezi, George Coşbuc, Nicolae Dabija, Ion Druță, Mircea Eliade, Mihai Eminescu, Paul Goma, Liviu Rebreanu, Mihail Sadoveanu, George Topârceanu and Grigore Vieru.

It is worth mentioning the volumes of prose written by Paul Goma, as well as Dr. Virgil Razseu, surgeon, animator of the scientific life, writer and journalist.

In "Leonid Gheorghian" collection we find 4 CDs with religious songs, located in the Mediateque and 3 documents, musical notes collections, located in the Loan Hall No. 3 Musical Documents, which denote the interest of the collcetion's owner to religious music.

"Pavel Proca" collection (Fig. 10, 11) comes from one of the most prolific theatrologist in the Republic of Moldova, who worked at the "Vasile Alecsandri" National Theater in Balti. For four decades, he watched everything that happened on the scenes and behind the scenes of the Moldavian theatre, filming chronics, making portraits, writing reviews of various performances on stage throughout the country.

Ion Ungureanu, Artist of the People, ex-Minister of Culture and Cults, mentions in his book "The Theater of My Life ...", launched on September 2, 2011, at the International Book Fair: "To Paul Proca, ....But I did not expect this ,star" of critics to come from Bălți. Another Basarabian miracle. What a nice thing we have: So it's not all lost in our culture..."

${ }^{6}$ Ion Ungureanu, Teatrul vietii mele... in trei acte si fara antracte (Chişinău : Cartea Moldovei, 2012), 622 p. 

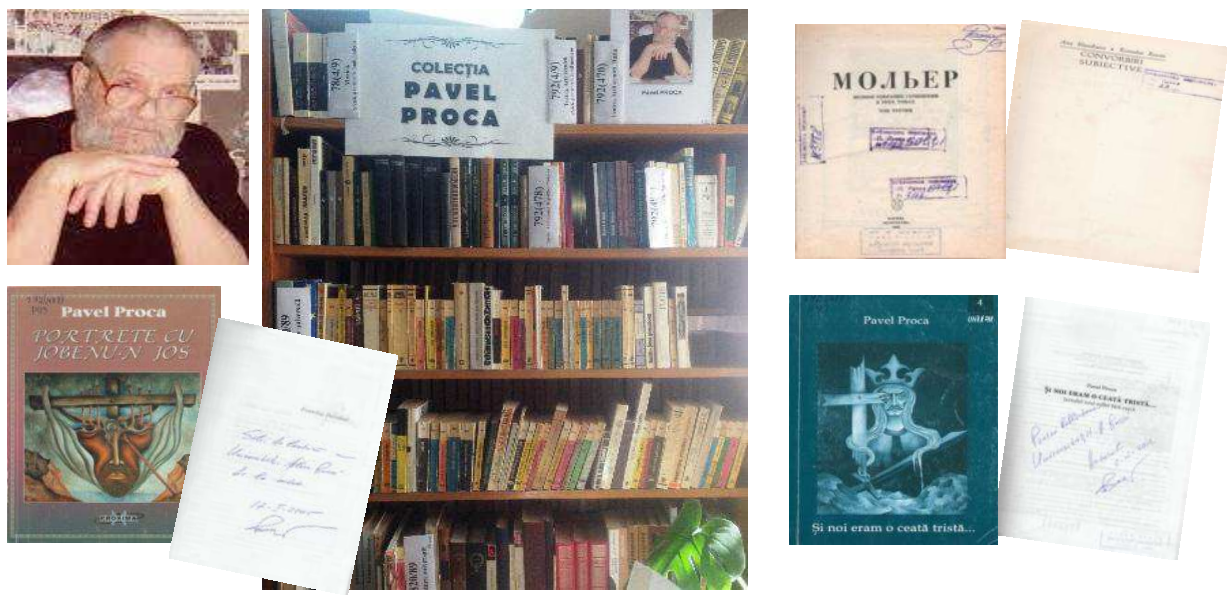

Fig. 10. The "Pavel PROCA" Collection

The donation includes 464 copies in 457 titles, including 179 new titles. The collection includes general-cultural spheres of interest (philosophy, real and applied sciences), and mostly specialty areas (art, fiction, history).

The themes of the works include the subjects specific to theatre and film: acting, dramaturgy, directing, scenography, criticism in Romanian, Russian, published in the publishing houses: Albatros, Moldavian Book, Romanian Book, Meridiane, Art, Fiction, etc.

Most books have the donor's ex-libris: "Personal P. Proca Library". Books are inventoried, we suppose they also had a catalogue for tracking, quick retrieval, and avoid duplicate titles. The highest inventory number we found was No. 1.3168 on the book Мольер, Жан Батист. Полное собрание сочинений: В 3 т. Т.3. - М. : Искусство, 1987. - 717 p. (Moliere, Jean Baptiste. Complete works: In 3 vol. T.3. - M. : Art, 1987. - 717 p.) It follows that P. Proca was the owner of over 3000 works.

Collections included: "Arcade", "Biblioteca de artă" (The Art Library), "Biblioteca pentru toți" (The Library for All), "Cele mai frumoase poezii (The Most Beautiful Poems), "Clasicii Literaturii Universale" (The Classics of Universal Literature), "Patrimoniu", "Rampa", "Romanul de dragoste" (Love novel), "Teatru" (Theater), "Texte comentate" (Commented Texts), «Античная Араматургия» (Antique drama), «КАассики и современники» (Classics and Contemporaries), «Мастера советского театра и кино» (Classics and Contemporaries), etc.
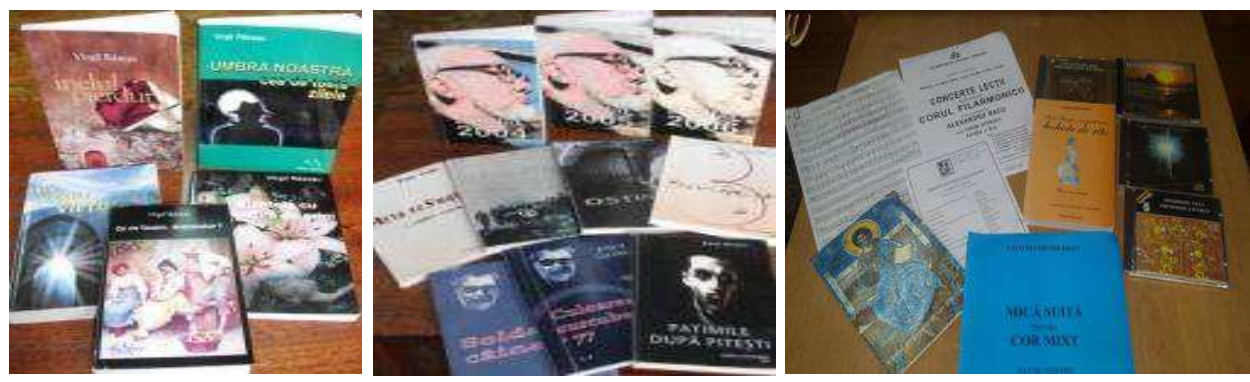

Fig. 11. The "Pavel PROCA" Collection 
The library is proud of the books of Pavel Proca ,playwright and art critic, which are included in the „Book of Autographs and dedications” catalogue, edited by the USARB Scientific Library, the authors being Lina Mihaluța, Elena Cristian and Svetlana Cecan.

The "Daniela Gifu" collection. Daniela Grifu is a graduate in Physics, master degree in Communication and $\mathrm{PhD}$ in Philosophy. At present she is a professor at "Alexandru Ioan Cuza" University of Iasi. "Daniela Gifu" collection includes 96 copies in 62 titles, personal works and other Romanian books. The whole content of the collection is positioned by the effect of providing users with the Romanian words. Daniela Gifu (Fig. 12) publishes prose, literary criticism, essays, portraits in numerous cultural and literature journals in the country and abroad, as well as in anthologies and collective volumes. Some documents in the collection have a special value, which is given by the dedication of their authors. Some of these dedications were personalized, addressed to Daniela Gifu: The writer and journalist George Arhip writes, To my Friend Daniela Gifu, an invitation to the Nameless Country, George Arbip Iasi, on 11 Dec. 2010; Autograph of Poet Aurel Pop - My good friend Daniela Gifu, we go in and out of the world through a fall. It all depends on us, we have stopped and kept the secret of these falls. Sincerely Aurel Pop March 2013; Mrs. Daniela Gifu, these steps to the highest Eminescu and human spirituality. Respectfully George Popa March 13, 2011.7

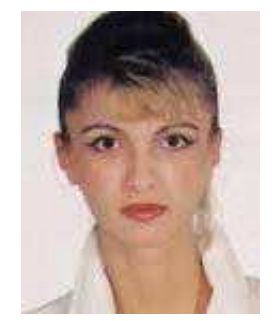

Fig. 12. Daniela GIFU

A number of documents have autographs by Daniela Gifu, out of which we feel her love for the Romanian country, people and language: Romanians from Bălţi live hopefully. Daniela Gifu 14.09.2014 Bălți; A pivotal bridge over the centuries. Romania-Moldova. With the joy of dedication. Daniela Gifu 11.09.2014, Bălti. Mrs. Daniela Gifu comes with a message to all editors in Romania "If each of them could donate to the Library of the University of Bălți one copy of each printed book, the symbolic "Bridge with Flowers," which was spoken about for a quarter of centuries, would turn into a concrete "Bridge of Romanian Books." It would be an invaluable help for those we call our brothers."

The "Dan-George Dimitrescu" collection (Fig. 13), obtained as donation in 2014, is the Dan George Dimitrescu family library. He graduated from Bucharest University of Engineering and worked as an engineer until his departure to Sweden in 1988. The collection includes 2608 documents in 2578 titles, including 1774 solo titles in various languages (Romanian, English, French, German, Latin, Italian, Spanish, Russian). A significant weight in this collection is represented by the works in Romanian, the majority

\footnotetext{
${ }^{7}$ Mihaluța, Lina, Cristian, Elena, Cecan, Svetlana. Colecția Daniela Gifu. In Carte cu autograf și dedicații : catalog. Bălți, 2015, vol. II, 261-268. ISBN 978-9975-50-152-1.

${ }^{8}$ Daniela, Gîfu. Criză de carte românească la Biblioteca Sttiințifică a Universităţii de Stat "Alecu Russo" din Bălți, http://uzp.org.ro/criza-de-carte-romaneasca-la-bibliotecastiintifica-a-universitatii-de-statalecu-russodin-baltii (accessed: September 15, 2015).
} 
edited at the beginning of the $20^{\text {th }}$ century. The rare book is represented by 410 volumes, and they can be classified as rare Romanian books and rare foreign books. The donor's great passions were books, geography, bridge, philately, and travel. The books reflect on the one hand the style and the intellectual interests of Dan George Dimitrescu and on the other hand his life and activities.
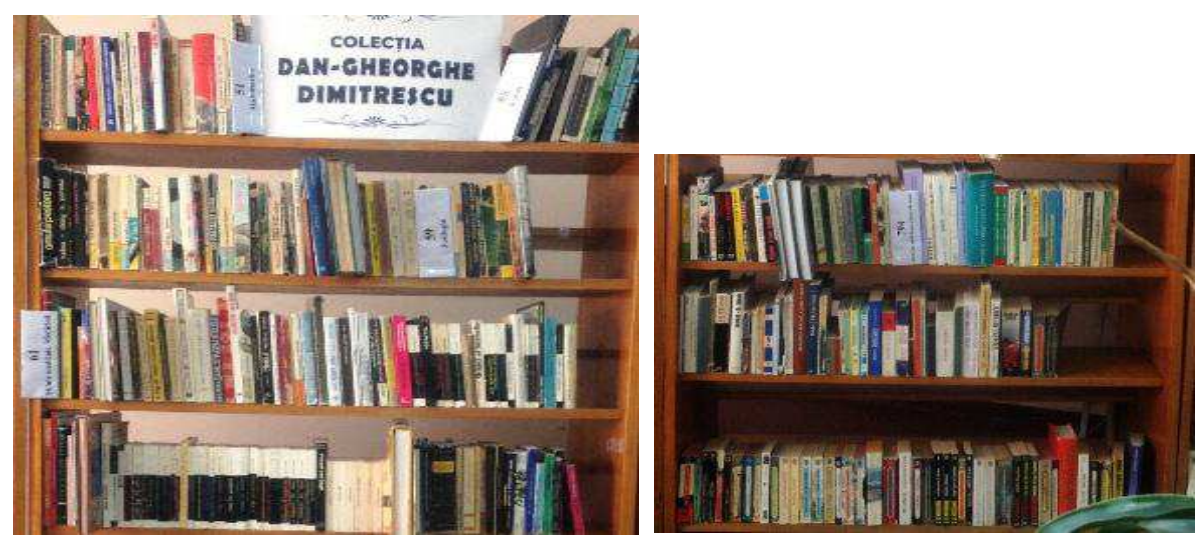

Fig. 13. The "Dan-George DIMITRESCU" Collection

The way the collection is presented shows the respect and special care of the owner for his books. Bonded and covered with rigid, flexible cover, they speak in their own style about the inseparable relationship between interest and passion for the bridge, the travelling, and the functions it has fulfilled. All documents bear the stamp of O. P. C. N Bucharest (Office of National Cultural Heritage). As a result, these cultural goods (books) were removed from the country. His daughter, Suzana Dimitrescu confesses about evidence of this episode of her father's life (all books were transported to Sweden, $5 \mathrm{~kg}$ per person).

Some of the books carry the author's notes and autographs, other simple inscriptions of the people who bought or donated them.

We present some dedications given to Dan George Dimitrescu:

A "modest" contribution to my competitive bridge! ... A dedication to my great maestro, to whom, with a friendly mind, I tell him that thanks to him, we have reached this level. Sincerely Andrei Varlan November 2003 or another autograph, On behalf of a friend and respect that I do not want to disappear. Andrei, May 2009; Mr. Dan Dimiterescu with all my esteem. From the father of the author M. Scarlat Sf V asile 2007; My high school colleague and my old friend Dan Dimitrescu With all my love Dominte Timonu 1/06/2012; Mr. Dan Dimitrescu with feelings of esteem and appreciation from the author Gh. Neamu, etc. ${ }^{9}$

The volumes are emphasized as patrimony values. We notice translations from foreign authors and works written by Romanian authors printed in the country and abroad. Passionate for culture, geography and history, Dan George Dimitrescu has gathered precious and rare books from different epochs and cultures.

The state of preservation of these books is good, which means that they will last for many centuries, and the next generations will give them the attention, respect and appreciation that these written sources of Romanian history and civilization deserve.

\footnotetext{
${ }^{9}$ Lina Mihaluța, Elena Cristian, Svetlana Cecan, "Colecția Dan George Dimitrescu.” [The Dan George Dumitrescu collection] in Carte cu autograf si dedicatii [Book with autograph and dedication]: Bălți catalogue 2015, vol. II, 247-260. ISBN 978-9975-50-152-1.
} 
In conclusion, we would like to quote a fragment from his daughter, Suzana Dimitrescu's evidence: "Dad was a good-hearted man who has been involved in the fate of many people trying to help them. We are glad that other literature enthusiasts will be able to enjoy the books so loved by our father."

The "Nicolae Varnay" collection was offered by his daughter. Dr. Nicolae Varnay was a lawyer, graduate of the Faculty of Law in Cluj. Besides the Hungarian mother tongue, he loved the Romanian language. He was self-taught in German and French, acquiring a pure culture in these languages. He worked as a lawyer in Arad, nicknamed „Gold mouth” for his pleadings in Romanian. He has grown up and lived in a multicultural environment Romanians, Hungarians, Germans, Serbs, Jews, and he strongly believed in friendship among peoples. He loved music and theatre. His whole life he worshiped his family and passion for books. This donation was made by the initiative and by the care of his daughter Ileana Budişteanu, architect, associate professor, doctor from Bucharest, Romania. Documents in the collection date back to the 20th century and include books in Romanian, Hungarian, German, French, etc. (Fig. 14).

\begin{tabular}{|l|c|}
\hline Hungarian & $\cdot 366$ \\
\hline English & $\cdot 243$ \\
\hline German & $\cdot 95$ \\
\hline English & $\cdot 24$ \\
\hline Italian & $\cdot 4$ \\
\hline Latin & $\cdot 2$ \\
\hline Russian & $\cdot 1$ \\
\hline
\end{tabular}

Fig. 14. Collections per languages

The "Nicolae Varnay" collection (Fig. 15, 16, 17) includes 852 papers in 848 titles in various fields of knowledge: linguistics, literature, theory, literary criticism, philosophy, religion, law, real science, medicine, art, history and 4 titles in Romanian language in religion field. The charm of the "Nicolae Varnay" collection is the harmonious coexistence between languages, $43 \%$ ) of them in Hungarian language being dominant. According to the genre of documents $51 \%$ are scientific documents, $46 \%$ are fiction and $3 \%$ didactic documents. 


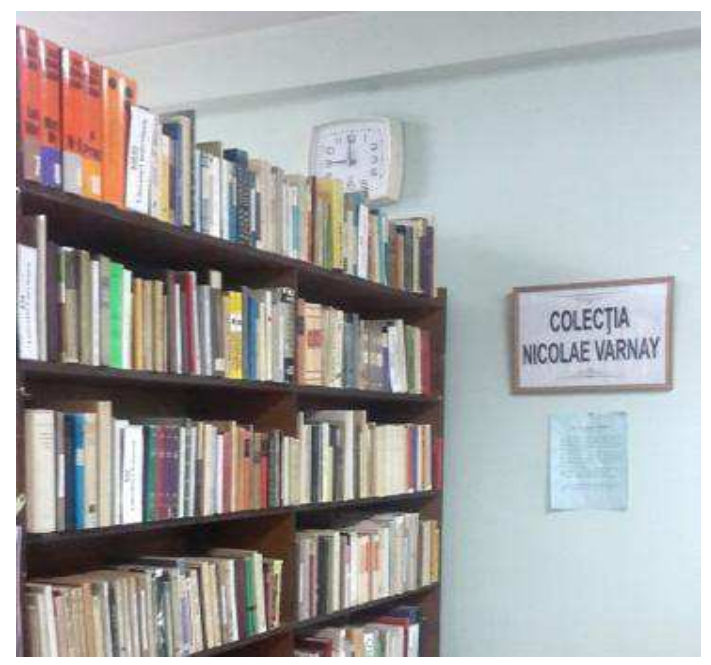

Fig. 15. The "Nicolae VARNAY" Collection

The volumes in the collection items date from the $19^{\text {th }}$ century to the present. An exceptional gift is the rare editions, the bibliophile books that are of interest not only in content but also in form, published during 1868-1955. We mention in particular the existence of bibliophile values:

- Almanach az 1892. evre: Egyetemes Regenytar / szerk. Kalman Mikszath. Budapest : Singer es Wolfner, 1892. - 251 p.

- Ady-dokumentumok konyve. - [Bratislava]: [Eugen Prager], [1937]. - 87 componente.

- Ghetie, Jon. Dicționar român-magiar : Pentru şcoală şi privaţi = Roman-magyar szotar : iscolai es maganhasznalatra / Jon Ghetie. - Budapest: Franklin-Tarsulat, 1896. $-501 \mathrm{p}$.

- Neuestes taschen-worterbuch deutsch und englisch. Ed.: F. E. Feller, O. Thiergen. - Leipzig: B. G. Teubner, 1898 (Kollektion Feller). - Vol.2. - 54 p.

- Maupassant, Guy de. Mont-Oriol; Yvette. forditotta: Frigyes Koranyi, eno Vertesy. - Budapest : Revai Testverek Irod. Int. R.-T., 1910. - 324 p. - (Klasszikus Regenytar / szerkesztik: Zoltan Ambrus, Geza Voinovich).

- Segur, Comtesse de. Les Bons enfants. Paris : Librairie Hachette, 1907. - 380 p.: il. - (Bibliotheque rose illustree).

- Tompa, Mihaly. Munkai: sajto ala rendezte es bevezetessel ellata Jozsef Levay. Budapest : Franklin-Tarsulat, 1902. - Kot.1-2. - (Magyar remekirok ; 37-38).

Kot. 1 : Dalok. Odak. - 1902. - 272 p.: portr.

Kot. 2 : Dalok. Odak. Romanczok. Balladak. $-1903 .-275$ p.

- Une Journee a Versailles: Guide illustre du chateau, du musee, du parc et des trianons. Paris : Braun \& C, 1937. - 68 p.: il. 


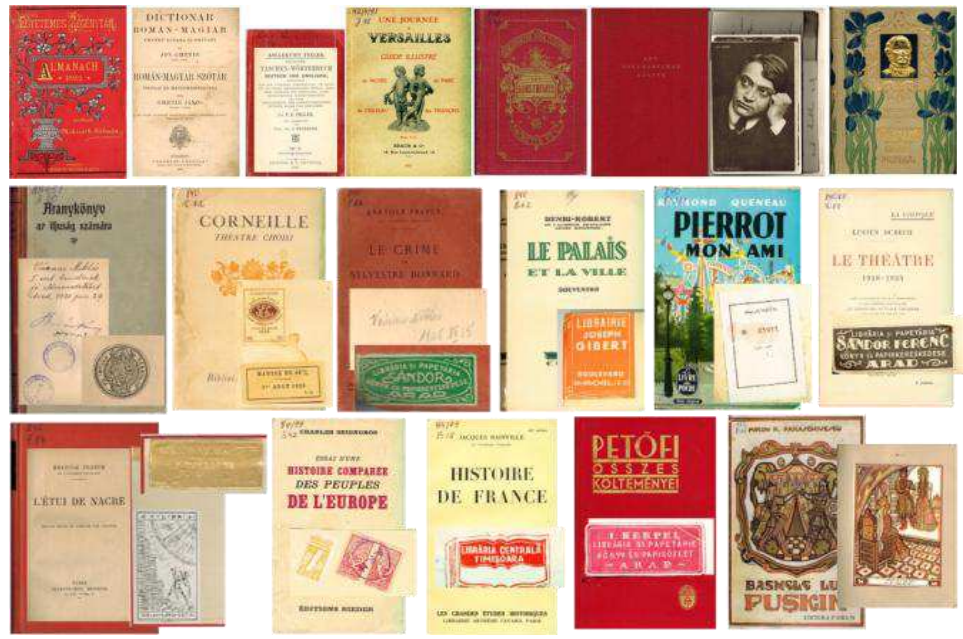

Fig. 16. The "Nicolae VARNAY" Collection

The category of valuable documents includes numbered copies, with autographs, illustrated books, as well as volumes with old manuscripts, ex libris or special binding techniques with stamps.

Some include notes of the lawyer, Dr. Nicolae Varnay: Les Plus beaux tableaux du Louvre (Paris: Libr. Hachette, 1929), L Ecole des femmes de A. Gide (Paris: Librairie Gallimard, 1929), Classe de E. Glaeser (Paris:Victor Attinger, 1929), Les Moins de vingt ans de Gyp (Paris: Calmann-Lévy, 1930). volumes.

The cultural profile of the bibliophile Nicolae Varnay, is illustrated by encyclopaedic

- Allam - es jogtudomanyi enciklopedia / foszerkeszto: Imre Szabo. - Budapest : Akademiai Kiado, 1980. - Kot. 1-2. - ISBN 963-05-2056-7.

- Bainville, Jacques. Histoire de France / Jacques Bainville. - Paris : Librarie Artheme F Ayard, 1924. - 574 p.
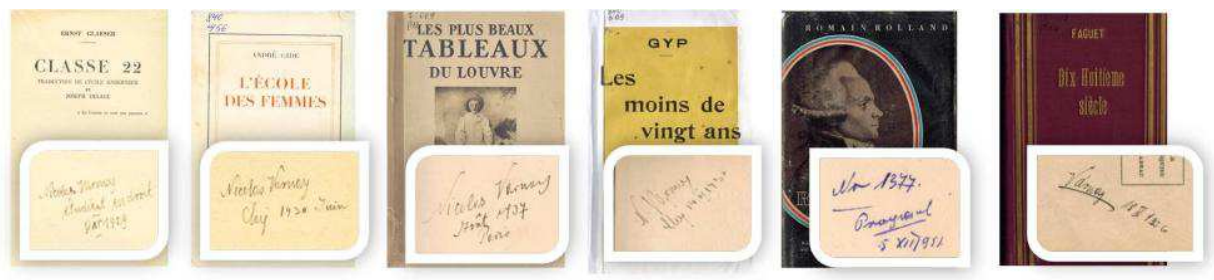

Fig. 17. The "Nicolae VARNAY" Collection

The donation presents precious collections, some of which are unique: Biblioteca de buzunar (Pocket library), Biblioteca pentru toți (The library for all), Biblioteca şcolarului (School Library), Bibliothèque Nationale, Bibliothèque rose illustree, Bibliotheca scriptorum graecorum et romanorum Teubneriana, Bibliothèque de philosophie scientifique, Bibliotheken der Weltlit, Cartea Vremii (The Book of Time), Classiques Larousse, Clepsidra, Cogito, Collection des écrivains illustres, Collection Europe, Columna, Deutsche Klassiker, 
Diakkönyvtar, Explication de notre temps, Fischer Bucherei, Gondolkodó magyarok, Grandes figure, Les grandes études historiques, Le Livre de poche, Lyceum, Mari Scriitori Români (Great Romanian Writers), Magyar remekirok, Meridiane, Nouvelle Bibliothèque Littéraire, Olcsó Könyvtár, Osszegyujtott muvei, Patrimoniu, Părinţi şi scriitori bisericeşti (Fathers and church writers), Remekírók Képes Könyvtára, Renaissance könyvek, Revai könyvtár, Romanul secolului XX (The Twentieth Century novel), Seria de autor "Jorge Luis Borges" (The author's series "Jorge Luis Borges"), Serie de autor Julio Cortazar (The author's series Julio Cortazar), Sinteze Lyceum,Tanulok Könyvtóra, Teatru (Theater), Teka, etc.

The collection acquired by the lawyer, Dr. Nicolae Varnay is distinguished by thematic and linguistic diversity, value and originality; the documents are particularly useful for both students and teachers to be used for studies and research, and for all those interested in Hungarian language, literature and culture.

The "Mircea Filip" collection (Fig. 18) was organized in the autumn of 2016. It was donated by Prof. Mircea Filip from Bucharest. The private collection "Mircea Filip" currently contains about 970 volumes in Romanian, English, French languages etc. This collection includes the documents from all fields of culture and science: philosophy, aesthetics, sociology, law, art, music, philology, works of art fiction, geography, history.

Many of these books have historical notes, ex-libries, dedications and autographs. Also, they have a great graphic presentation, a generous and useful cultural approach that comes with useful information for library users, enriching the SLUSRB collection with new book titles. Analyzing the 1908-1960 editions, these include about 248 books, most of them unique, of which the oldest copies are:

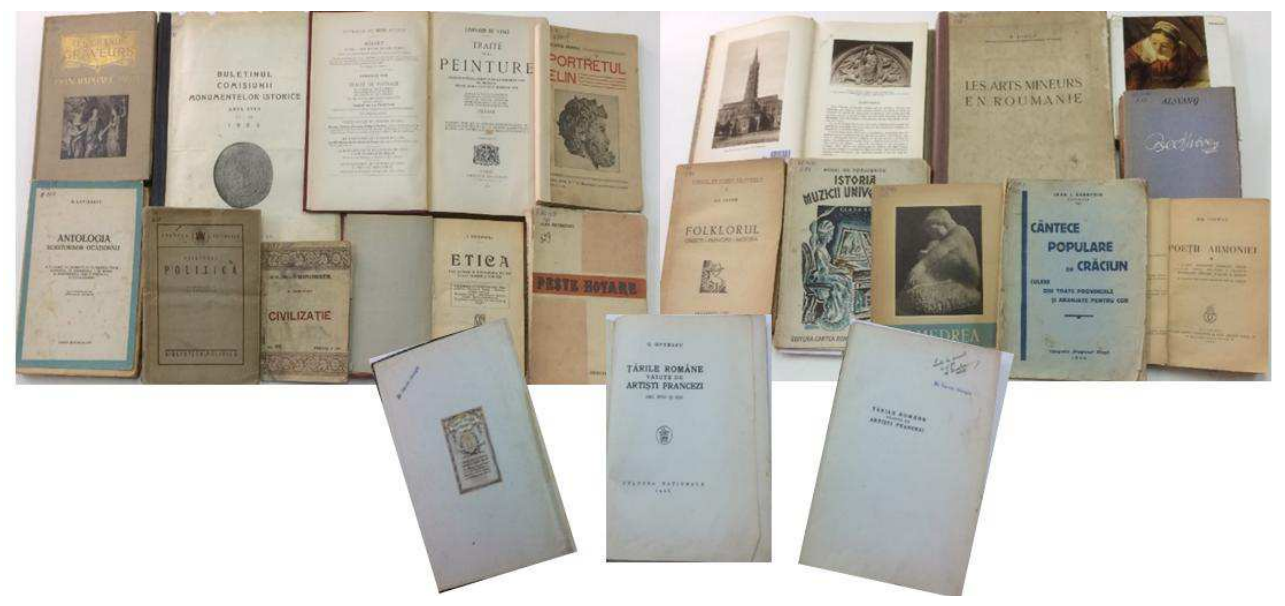

Fig. 17. The "Mircea FILIP" Collection

- Murnu George. Portretul Elin: Studiu iconografic din arheologia clasică cu 15 ilustrațiuni în text. Bucureşti: Inst. de Arte Grafice "Carol Gobl" (1908), îmbogăţită cu autograful "Lucreția Zamfirescu 1914".

- John Raphael Smith et les graveurs a la maniere noire du temps de Reynolds. Paris: Hachette et Cie (1914), cu 64 de gravuri engleze din secolul al XVIII-lea: Thomas Frye. La Reine Charlotte, femme de George III; James McArdell. Mary Panton, duchesse d'Ancaster (Hudson); Anne Day, devenue Lady Fenhoulet (Reynolds); Laurence Sterne (Reynolds); Emma Lyon, Lady Hamilton posant une "Nature" (Romney), etc. Cartea deține un ex-libris ştampilă: Librăria "CARMEN SYLVA". 
- Leonard de Vinci. Traite de la Peinture: traduit integralement pour la premiere fois en francais sur le Codex Vaticanus (Urbunas) 1270. Ouvrage orne de 40 fig. Demonstratives de l'edition Princeps et de 100 dess. Esthetiques d'apres les Cliches d'Alinari, Brogi et Fumagalli. Paris. Librairie Delagrave, (1919).

From the field of art, music we can mention the valuable documents that support the desire to know the miraculous world of beauty, the spiritual world:

- Posluşnicu, Mihai Gr. Istoria muzicii universale: Forme muzicale la popoarele occidentale şi la români: pentru clasa 6-a secundară de ambele sexe. Bucureşti: Cartea Românească, (1935).

- Ciomac, Em. Poeţii armoniei: I. S. Bach, Beethoven. Schumann, Chopin, Liszt, Verdi, Brahms, C. Franck, Mussorgsky, Debussy, M. Ravel, G. Enescu cu 12 portrete dupa desenele originale de Jean Al. Steriadi. Bucureşti : Fundația pentru lit.şi artă „Regele Carol II”, (1936).

- Cuclin, Dimitrie. Manual de muzică pentru clasa I-a secundară. București: Cartea Românească, (1936).

There are over 100 volumes in the collection containing handwritten notes or autographs that specify who wrote them.

Among heritage books in the collection of "Mircea Filip" we find a special one through the ennobled information on her pages. The book, Oprescu, G. Romanian countries seen by French artists (XVIII and XIX centuries). Bucharest: National Culture, (1926), holds the autograph "The 1st Prize taken in the $7^{\text {th }}$ grade Gh. Maraloi 1934-35,", ex-libris label: ROYAL CULTURAL FOUNDATIONS. This book is given by King Carol II via the Royal Cultural Foundation to youth education and to reward the students who are on the path of exploring the culture, and another ex-libris stamp Dr. Maraloi Gheorghe.

The volumes of private collections ,bear the traces of the time and touch of those who have browsed them before, their beauty is the beauty of the thought gathered in the miracle of the letters..." 10

The Scientific Library of the Alecu Russo Balti State University expresses its gratitude to the donors and families of Mr. Radu Motoc, Mircea Druc, Ioan Calin Dimitriu, Leonid Gheorghian, Pavel Proca, Dan-George Dimitrescu, Daniela Gifu, Iulius Popa, Nicolae V arnay, Mircea Filip, Ioan Nicorici for the valuable collections of books that came to Balti and can be read today with as much passion as years ago.

\section{References}

Cazacu, Gabriela. "Bibliotecile sunt eterne datorită pămîntenilor cu suflet mare [despre Colecția Mircea Druc de la BŞ USARB]" [Libraries are eternal because of big-hearted poeple - on the Mircea Druc Collection of BŞ USARB]. Sintagmele V (2014): 7.

Cristian, Elena. "Colectia particulara a Dlui Ion Calin Dimitriu integrata în colectia Bibliotecii Stiintifice USARB" [The private collection of Mr. Ion Calin Dimitrtiu from the Collection of the Scientific Library of USARB]. Confluente bibliologice 3-4 (2014) : 117124, http://libruniv.usarb.md/confbib/articole/2014_3-4/Conf\%203-4,2014\%20117-

10 Stoica, Ion. Informație și Cultură : sintez̧e, reflecții, atitudini. Bucureşti : Editura Tehnică, 1997, 149. 
124.pdf, http://www.calameo.com/books/001133349bb964f950861 (accessed: November 23, 2017).

Gîfu, Daniela. Criză de carte românească la Biblioteca Științifică a Universității de Stat „Alecu Russo" $\operatorname{din}$ Băltiti [The Romanian book crisis at the Scientific Library of the "Alecu Russo" State University of Bălți], available online at: http://uzp.org.ro/criza-de-carte-romaneasca-labibliotecastiintifica-a-universitatii-de-statalecu-russo-din-baltii (accessed: September 15, 2015)

Iulius Popa Collection, available online at: http://bsusarb.blogspot.com/search?q=colec $\%$ C5\%A3ia+iulius+popa (accessed: November 23, 2017).

Leiter, R.A. "Reflections on Ranganathan`s Five Laws of Library Science." Law Library Journal 96(3) (2003): 411-418.

Mihaluța, Lina and Elena Cristian, Svetlana Cecan. "Colecția Daniela Gifu" [Daniela Gifu Collection]. 261-268. In Carte cu autograf și dedicatii: catalog [Book with autograph and dedications: catalogue]. vol. II. Bălți: 2015,. ISBN 978-9975-50-152-1.

Mihaluța, Lina and Elena Cristian, Svetlana Cecan. "Colecția Dan George Dimitrescu" [Dan George Dumitrescu Collection]. In [Book with autograph and dedications: catalogue]. vol. II. Bălți: 2015,. ISBN 978-9975-50-152-1.

Pop, Ioan Aurel (ed.). Sunt român şi limba mea-i română [I am Romanian and my Language is Romanian]. Chişinău: Litera, 2014.

Ungureanu, Ion. Teatrul vietii mele... in trei acte si fara antracte [The theatre of my life... in three acts without intermission]. Chişinău: Cartea Moldovei, 2012. 622 p. ISBN 978-9975-60236-5.

Stoica, Ion. Informație şi Cultură : sintęe, reflecţii, atitudini [Information and Culture. Summaries, Reflections, Attitudes]. Bucharest: Editura Tehnică, 1997. 227 p. ISBN $973-$ 31-1097-3. 